\title{
ARTICLES
}

\section{A MINIMAL ROLE FOR MINIMUM TAXES}

\author{
Steven M. Sheffrin*
}

\begin{abstract}
The 2017 Tax Cuts and Jobs Act eliminated the alternative minimum tax for corporations and sharply eviscerated the alternative minimum tax for individuals. Yet recently there has been a resurgence of interest in minimum taxes both for the international tax systems and in certain domestic contexts.

This Article argues that there should be a role, but a very minimal one, for minimum taxes in our tax system. While reasonable arguments have been put forward for minimum taxes, on closer examination, many of these arguments are found wanting. This Article, however, does make a second-best case for one type of minimum tax, namely as a backstop for a potentially flawed or deficient tax. That is the "minimal role for a minimum tax."

To develop this argument, I explore three distinct theoretical rationales for minimum taxes that have been put forward. First, I discuss the distinction between unilateral and multilateral minimum taxes and the potential role that multilateral minimum taxes can play in alleviating concerns that arise from tax competition and the presence of tax havens. While unilateral minimum taxes may have a strong rationale, the rationale for multilateral minimum taxes is not compelling. Second, I show how considerations of fairness, public perception, and alternative views of the corporation create a demand for minimum taxes. This demand, however, can be satisfied in other ways. Finally, I discuss how the imperfect targeting of tax preferences and practical limitations in the design and effectiveness of the most common taxes can provide a potential, but limited, efficiency rationale for the use of minimum taxes. I lastly provide an example of the use of minimum taxes for reforming state corporate taxation.
\end{abstract}

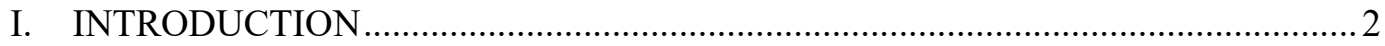

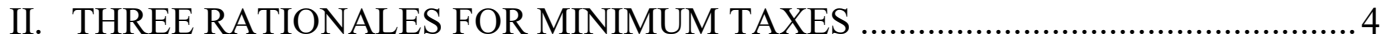

A. Multilateral Minimum Taxes ........................................................................... 4

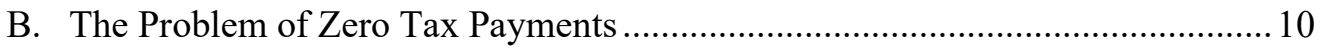

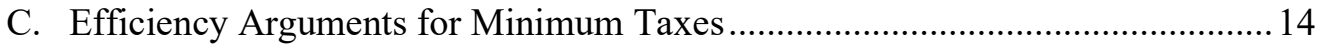

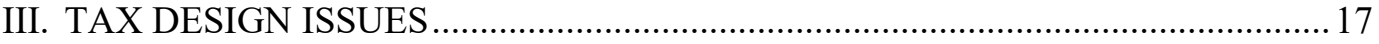

\footnotetext{
* Professor of Economics and Affiliated Professor of Law, Tulane University. I would like to thank Mary Penn and Spencer Landry for research assistance on this project. Daniel Groft, formerly of the Louisiana Department of Revenue, kindly provided data for this Article. Janet Schwartz, Michele Hanlon, and Drew Lyon all pointed me to interesting research on this topic. James Alm and Katie Weaver provided valuable comments on earlier drafts.
} 
A. Policy Drift and the Individual and Corporate Alternative Minimum Taxes ...... 17

B. Accounting Bases for Alternative Taxes .............................................................. 19

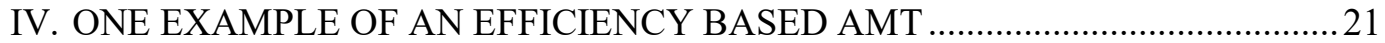

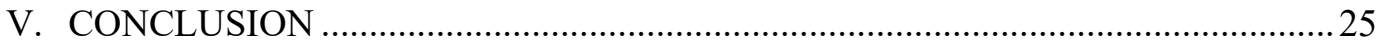

\section{INTRODUCTION}

In 1969, in the wake of publicity about a very small number of very high-income individuals not paying any income tax, Congress created two new minimum taxes-one for individuals and one for corporations. These taxes were enacted to avoid having taxpayers employ a variety of tax preferences, including deductions and exclusions, to pay zero or very limited amounts of tax. Although such methods were legal, their outcomes were perceived by the general public as both unfair and politically unacceptable. Over time, the two minimum taxes evolved to become the alternative minimum tax (AMT) for individuals and the corporate AMT.

Nearly fifty years later, the Tax Cuts and Jobs Act of 2017 (TCJA) eliminated the corporate AMT and sharply decreased the AMT that applied to individuals, trusts, and estates. For 2018, the Tax Policy Center estimated that only 200,000 taxpayers would be subject to the AMT compared to approximately 5 million before the TCJA was enacted. ${ }^{1}$

What happened over those fifty years to cause this change? Do the changes in the TCJA mean that the concerns that prompted the creation of the alternative minimum taxes have disappeared? Should minimum taxes still play an important role in our tax system? These are the issues I address in this Article.

Over a fifty-year period, as the alternative minimum taxes evolved and adapted to other major tax legislation, they became increasingly complex and created unintended consequences. The corporate alternative minimum tax was particularly complex, requiring, for example, that corporations use three different accounting systems to determine income subject to the tax. Scholars also demonstrated that the provisions of the tax could easily create inefficient investment incentives. ${ }^{2}$ The individual AMT became very complex in an era before tax preparation software was ubiquitous. Moreover, the tax lost its focus on preventing very high-income individuals from paying little tax. Instead, it transformed into a tax that primarily affected the upper-middle class, effectively taking away relatively uncontroversial deductions, such as those for state and local taxes. Because of these problems, reformers had long targeted the AMTs for either repeal or restructuring. Although they have largely disappeared from the tax landscape for the time being, many individual provisions in the TCJA are scheduled to expire in 2025, which will effectively bring the individual AMT back in full force.

Beyond this uncertainty, other minimum taxes are still present in both state and federal tax codes and new ones have been contemplated. The TCJA created a new tax on

* Professor of Economics and Affiliated Professor of Law, Tulane University. I would like to thank Mary Penn and Spencer Landry for research assistance on this project. Daniel Groft, formerly of the Louisiana Department of Revenue, kindly provided data for this Article. Janet Schwartz, Michele Hanlon, and Drew Lyon all pointed me to interesting research on this topic. James Alm and Katie Weaver provided valuable comments on earlier drafts.

1 See Tax Policy Center, How did the TCJA change the AMT? (May 2020), https://www.taxpolicycenter.org/briefing-book/how-did-tcja-change-amt-0 [https://perma.cc/A6LK-SDVL].

${ }^{2}$ For an extensive analysis of the inefficiencies deriving from the corporate alternative minimum tax, see Andrew B. Lyon, Cracking the Code: Making Sense of the Corporate Alternative Minimum TaX 62-128 (1997). 
Global Intangible Low Tax Income (GILTI) which, while very complex, effectively operates as a minimum tax on foreign-sourced income. ${ }^{3}$ It also eliminated carrybacks of tax losses, preventing current tax payments from falling below zero. ${ }^{4}$ The OECD has proposed a global minimum tax (GLoBE) as part of the continuation of the Base Erosion and Profit Shifting (BEPS) project which resembles the United States' GILTI as well as its base erosion and anti-abuse tax (BEAT), which was also enacted by the TCJA. ${ }^{5}$ The European Union (EU) already imposes minimum rates for the Value Added Tax (VAT) on its member countries. At the level of state government in the United States, a few states have franchise taxes which serve as minimum taxes for their state corporate income taxes.

What role should minimum taxes play in a tax system? Should those who make tax policy aim to eliminate these taxes, or do they have a lasting role to play in complex tax systems? This Article argues that there should be a role, but a very minimal one, for minimum taxes in our tax system. Our prior experience with minimum taxes has shown that they drift from their original purposes and become an unstable part of the tax system. While reasonable arguments have been put forward for minimum taxes, on closer examination, many of those arguments are found wanting. This Article, however, does make a second-best case for one type of minimum tax, namely as a backstop for a potentially flawed or deficient tax. That is my "minimal role for a minimum tax."

To develop this argument, I explore three distinct theoretical rationales for minimum taxes that have been put forward. First, I discuss the distinction between unilateral and multilateral minimum taxes and the potential role that multilateral minimum taxes can play in alleviating concerns that arise from tax competition and the presence of tax havens. While there are reasonable arguments for unilateral minimum taxes, the case for multilateral minimum taxes, however, is not compelling. Second, I show how considerations of fairness, public perceptions, and alternative views of the corporation create a demand for minimum taxes. This demand could, in principle, be satisfied in other ways. Finally, I discuss how the imperfect targeting of tax preferences and practical limitations in the design and effectiveness of our most common taxes can both provide a potential, but limited, efficiency rationale for the use of minimum taxes. In discussing each of these three rationales I provide a critical assessment of the arguments that have been put forward in favor of minimum taxes.

I then turn to some of the implementation issues that have arisen in the design and implementation of minimum taxes, focusing on the issue of the relationship between the

${ }^{3}$ For a general discussion of GILTI, see Susan Morse, GILTI: The Co-operative Potential of a Unilateral Minimum Tax, 4 BRIT. TAx REV. 512 (2019).

${ }^{4}$ The Coronavirus Aid, Relief, and Economic Security CARES Act, 15 U.S.C. Ch. 116 (2020), which was signed into law on March 27, 2020, temporarily reinstates the ability to carry back losses to past tax years. For a discussion of these provisions, see I.R.S., IRS Provides Guidance Under the CARES Act to Taxpayers With Net Operating Losses (Apr. 9, 2020), https://www.irs.gov/newsroom/irs-provides-guidance-under-thecares-act-to-taxpayers-with-net-operating-losses [https://perma.cc/MXW6-L4UY].

${ }^{5}$ The GloBE is discussed in the OECD public consultation document: Organisation for Economic Co-Operation and Development [OECD], Global Anti-Base Erosion Proposal ("GLoBE”)—Pillar Two (Nov. 8, 2019), http://www.oecd.org/tax/beps/public-consultation-document-global-anti-base-erosion-proposalpillar-two.pdf.pdf [https://perma.cc/SR7H-3FAK].

${ }^{6}$ After completing this article, I came across the work of Daniel Shaviro. Shaviro's focus in his paper is primarily on the taxonomy of minimum taxes and the potential for arbitrage and the possibility of discontinuous marginal tax rates. My focus is more on the empirical and psychological arguments in favor of minimum taxes and our historical experience with them. See Daniel Shaviro, What are Minimum Taxes and Why Might One Favor or Disfavor Them? (N.Y.U., Law and Econ. Paper Series, Working Paper No. 20-38, 2020). 
tax bases for the regular tax and the alternative minimum tax and the problems that arise from these interactions. I draw on the historical U.S. experience with respect to the evolution of the individual and corporate AMTs to demonstrate these points. I also discuss the range of issues that would arise from using book income as a base for an alternative minimum tax. Finally, I illustrate the use of minimum taxes in the state corporate tax context for a potential reform.

I conclude that both fairness and efficiency considerations may warrant minimum taxes in some carefully circumscribed and second-best circumstances. For the reasons I discuss in this Article, these taxes will not go away. They should therefore be structured as carefully as possible to do minimal harm. They should be "boutique taxes" and not "mass taxes" to avoid the historical problems we have witnessed with our minimum taxes.

II.

\section{THREE RATIONALES FOR MINIMUM TAXES}

Before discussing the theoretical rationales for minimum taxes, a few definitions will be helpful. I will define minimum taxes as any taxes that are designed to place a floor - which typically, but not necessarily, will be taxpayer-specific - on the taxes paid by any entity. Alternative minimum taxes are those taxes that use an alternative base to compute the minimum tax. So, for example, a rule that specified a minimum ten percent rate on foreign-sourced income - regardless of what rate was levied by a foreign countrywould clearly be a minimum tax, whereas a state using a franchise tax calculation to place a floor on a corporation's state income tax would be deemed an alternative minimum tax. Alternative minimum taxes are thus a subset of minimum taxes in our terminology.

In this section, I discuss and evaluate three different rationales for minimum taxes. The first perspective is based on the role that minimum taxes could play in ameliorating concerns arising from tax competition and the use of tax havens. Here, the minimum taxes would arise from a multilateral agreement. As I discuss below, these ideas have been put forward in the international tax context.

The second rationale traces back to the original motivations for the AMT in the United States. Even when individuals or corporations are complying with the rules and regulations of the tax system and employing legitimate deductions, exclusions, credits, and other tax preferences, an outcome that results in zero tax payments or limited payments for taxpayers may appear unfair and unacceptable to many in the public. An important issue is how corporations are conceived - are they just conduits for shareholders or viewed as entities in themselves? If the public holds the latter view, then corporations that do not pay taxes will draw the public ire and create perceptions of unfairness in the tax system.

The third and perhaps most important rationale is the role that minimum taxes can play in promoting economic efficiency. The insight here is that minimum taxes can serve as a safeguard or backstop against overly broad tax incentives and provisions of the tax code that are difficult for tax administrators to monitor and that can be too easily manipulated by taxpayers. In these cases, minimum taxes serve as tools to prevent problems that emerge in the tax system because other components of the system are imperfect.

A. Multilateral Minimum Taxes

A jurisdiction may levy its own minimum tax regardless of the taxes levied by other countries or jurisdictions. These are unilateral minimum taxes. On the other hand, a jurisdiction may levy a minimum tax as a part of a coalition of other jurisdictions. These are multilateral minimum taxes. 
As an example of a multilateral minimum tax, consider the VAT within the EU. According to EU rules, member countries must impose a VAT no lower than $15 \%$. This is the minimum rate. There are exceptions for up to two reduced rates (the lowest not being less than 5\%) for a specific set of goods and services listed in Annex III to the EU VAT directive. These goods include food for home consumption, drugs, and a variety of other items. There are also "super-reduced" rates that were in place prior to 1991, which were grandfathered in. ${ }^{7}$

Why does the EU require a minimum basic tax rate for the VAT? The essential reason is that this minimum rate is designed to limit competition between countries on taxes within the EU. The implicit belief is that without this minimum rate there would be "excessive" tax competition, driving down tax rates and causing a drain on financing for public services. The EU countries thus agreed to the minimum rate as a political disciplining device to avoid competition between member states and to provide a floor to their public budgets.

While minimum tax rates can set a floor, whether minimum tax rates in fact lead to overall higher tax rates is not conclusive from the standpoint of economic theory. States that were considering setting rates above a proposed minimum might lower their rates to the minimum, reducing the variance of tax rates. In the EU this has not been the case, with the largest economies having rates around $20 \%{ }^{8}$ If anything, there is a "race to the middle" rather than a race to the bottom. France, Germany, Belgium, the United Kingdom, Spain, and the Netherlands all have rates between 19 and $21 \% .{ }^{9}$ Luxembourg at one time had a rate of $15 \%$ but its current rate is $17 \%$.

The rationale for a minimum VAT rate may be more political than purely economic. The VAT is a consumption tax and falls primarily on domestic consumers-it is imposed on imports and removed on exports. As a consumption tax, the VAT is levied on the destination so that a high rate in France affects French consumers, not German consumers. In principle, then, the French could choose a high rate for their country and not adversely affect the flow of goods or capital between France and Germany. ${ }^{10}$ One technical argument in favor of synchronization or harmonization of rates is that a major discrepancy in VAT rates could lead to some unreported cross-border shopping. However, this is probably not as important as a country feeling that it is a "political outlier" with a higher rate of tax. Imposing a high minimum tax therefore provides a safeguard for domestic politicians.

On the corporate side, tax avoidance and tax competition are much less straightforward. Countries are concerned with profit shifting to tax havens as well as with competition among more traditional economic rivals. As has been well-documented, an important component of tax competition has often involved the use of tax havens in complex arrangements that exploited uncoordinated features in corporate law as well as

\footnotetext{
${ }^{7}$ For a concise discussion of the European Union VAT rules, see Ian Crawford, Michael Keen \& Stephen Smith, Value Added Taxes and Excises, in Dimensions of TAX DESIGN: The MirRleEs Review 275, 297-99 (Inst. For Fiscal Stud. ed., 2010).

${ }^{8}$ For a listing of current VAT rates, see 2020 European Union VAT Rates, AvalaRA (2020) https://www.avalara.com/vatlive/en/vat-rates/european-vat-rates.html [https://perma.cc/R773-ZQKE].

${ }^{9}$ The United Kingdom is no longer in the European Union but has not yet adjusted its VAT rate.

${ }^{10}$ Similar arguments were made that a consumption tax rate did not affect international tax competition during the discussion of the potential adoption of the border adjusted cash flow tax in the United States For a discussion of the border adjusted cash flow tax in terms of a consumption tax, see Alan Auerbach, Demystifying the Destination-Based Cash-Flow Tax, Brookings PAPERS On ECON. ACTIVITY 409 (2017).
} 
the inherent difficulties of using transfer pricing methods for intangible assets. ${ }^{11}$ There are also successful examples of tax competition providing substantial economic benefits to countries that offer lower rates, apart from offering access to tax havens to the corporations taking advantage of those rates. Ireland is an example of a country that has benefited from lower rates in attracting foreign investment. ${ }^{12}$

In February 2019, the OECD discussed a proposal for a minimum tax on the profits of multinational firms, dubbed the GLoBE "global anti-base erosion proposal." 13 In November 2019, the OECD issued a public consultation document for the GLoBE proposal, the second in a series of proposals for reforms of international taxation, spelling out the proposal in more detail. ${ }^{14}$

Resolving design issues and obtaining international agreement is a much more difficult task for corporate minimum taxes than it is for the VAT. Not only are corporate taxes fundamentally different from personal consumption taxes, but the corporate taxes would need to cover a much wider range of countries than those encompassed by the EU. One challenge is that the United States, in 2017, adopted some elements of the minimum tax philosophy in the enactment of the GILTI and the BEAT, but did so on a unilateral, not multilateral, basis.

Proponents of minimum taxes on the profits of multinationals have offered several rationales. As Englisch and Becker discussed, a minimum rate can move countries closer to the goal of capital export neutrality (each country taxing income of its resident firms and individuals at the same rate regardless of the source of the income), thereby promoting economic efficiency by ensuring that the pretax rate of return of capital is the same in all jurisdictions. In addition, minimum rates can prevent the diversion of reported profits to tax havens, ensuring that multinationals do not use these havens to escape taxation. If most major countries impose similar minimum taxes on foreign income, the benefits of zero or low taxes in tax havens can be limited. In their recent book, Emmanuel Saez and Gabriel Zucman make a similar argument. ${ }^{15}$

The argument here is that multilateral minimum taxes can in principle provide benefits to a group of countries. Since capital is mobile, there is pressure for countries to reduce their tax rates to attract foreign investment. Access to tax havens only exacerbates this pressure. Minimum taxes, according to this view, can prevent a race to the bottom which might threaten the public finances of countries. They can also be a tool to deal with

${ }^{11}$ The literature on this topic is vast. For a recent estimate of profits in tax havens, see Jennifer Blouin \& Leslie Robinson, Double Counting Accounting: How Much Profit of Multinational Enterprises is Really in Tax Havens? (May 20, 2020) (unpublished manuscript) (on file with author) (https://papers.ssrn.com/sol3/papers.cfm?abstract_id=3491451). An early statement of the complex methods used to avoid global taxation can be found in Edward D. Kleinbard, Stateless Income, 11 FLA. TAX REV. 699 (2011).

${ }^{12}$ While Ireland has attracted foreign investment and grew rapidly over the last 30 years, exact measurements are difficult as some profits may be simply shifted to Ireland. For a popular account of some of these difficulties, see Understanding Ireland's 'Unreal' Economic Growth, EOLAS MAGAZINE (Sept. 2016), https://www.eolasmagazine.ie/understanding-irelands-unreal-economic-growth/ [https://perma.cc/Y68EW5LK].

${ }^{13}$ For an analysis of the proposal, see Joachim Englisch \& Johannes Becker, International Effective Minimum Taxation - The GLOBE Proposal, 11 WORLD TAX. J. (2019).

${ }^{14}$ Organisation for Economic Co-Operation and Development, supra note 5.

${ }^{15}$ Emmanuel Saez \& Gabriel Zucman, The Triumph of Injustice: How the Rich Dodge TaXes AND How TO MAKE THEM PAY, 67-87 (2019). 
diversion of profits of multinationals to tax havens. Finally, they are consistent with traditional notions of economic efficiency in terms of capital export neutrality.

There are two traditional counterarguments against curtailing tax competition. First, arguments against curtailing tax competition rely on the notion of broadly wellintentioned governments. Yet if one takes the position that governments are largely rentseeking Leviathans, then minimum taxes become presumably successful oligopoly strategies for a collection of Leviathan states. ${ }^{16}$ Second, a case can also be made for legitimate tax competition in the presence of differential social benefits from investment, taking into account the external effects of investment. ${ }^{17}$ For example, a country may believe that the spillover effects from foreign investment create a divergence between private and social rates of return. In turn, the country would want to provide subsidies in some manner to foreign investors to attract new investment. This would be an example of socially beneficial tax competition. Resolving whether these arguments in favor of tax competition outweigh the conventional wisdom against tax competition, though, would take us beyond the scope of this Article.

Aside from this issue, there is an important limitation to the necessity of multilateral minimum taxes. To best understand this limitation, consider an alternative international tax system - a worldwide tax system with foreign tax credits. Until 2018, the United States taxed worldwide income of corporations but provided a foreign tax credit. While the United States allowed for deferral for income earned from foreign corporations and, aside from Subpart F income, generally only taxed dividends when they were repatriated, one could imagine a system without deferral so that all income would be taxed as it was earned. ${ }^{18}$ With a full foreign tax credit, capital export neutrality would be preserved. Moreover, if countries agreed to implement a similar worldwide system and limit the range of their tax rates, this would also prevent income from escaping tax by being shifted to tax havens. The proposals in the OECD Pillar Two proposal aim to create a worldwide tax system with coordinated minimum tax rates, not unlike our hypothetical system. We can then ask the question: why is the OECD Pillar Two system a more realistic scenario than a worldwide credit system with coordinated rates?

It is not clear that it would be, absent other important differences. Now, of course, the United States did allow deferral, and other major economic powers had more of a territorially based system than a worldwide system of taxation. These divergent policies allowed for economic competition in the face of countries having different tax rates and placed extensive pressure on the U.S. corporate tax system with its higher statutory tax rates. With the TCJA, the United States sought to alleviate some of this pressure by partly moving to a territorial system by allowing a dividend exemption. However, it did not go all the way by allowing a full exemption on active foreign source income and instead enacted GILTI to provide some basic level of minimum taxes.

Although the acronym GILTI contains the term "intangible," it applies to all income to corporate shareholders of controlled foreign corporations on a global basis in

\footnotetext{
${ }^{16}$ For a summary of the argument, see Deepak Lal, Restraining Leviathan, Bus. STANDARD (Jan. 19, 2013), https://www.business-standard.com/article/opinion/deepak-lal-restraining-leviathan-1130119000691 .html [https://perma.cc/8LQQ-DMDS].

${ }^{17}$ See David Elkins, The Merits of Tax Competition in a Globalized Economy, 91 IND. L.J. 905 (2016).

${ }^{18}$ Subpart $\mathrm{F}$ income is a category of income defined in $\S 952$ of the Internal Revenue Code for controlled foreign corporations that is included immediately in shareholders' income and not allowed deferral. It generally refers to income that is passive or easily mobile.
} 
excess of ten percent on invested foreign assets. That income could be profits from intangible assets or simply measured returns from other investments exceeding ten percent. This income is included in the current tax year in a shareholder's income. There is a $50 \%$ deduction for GILTI income, which brings the effective tax rate on foreign income below domestic rates. A foreign tax credit of $80 \%$ is allowed, although technical limitations on the scope of the credit, including expense allocations rules, may effectively disallow some portion of the tax credit. ${ }^{19}$

Key to making these new provisions work for the United States in terms of foreign tax competition was the overall new lower U.S. corporate tax rate of $21 \%$ (and even a lower rate for foreign source income due to the deduction for GILTI). With U.S. rates on foreign source income now near or even below the rates of our primary competitors, the U.S. could end deferral (with its inefficient overhang of unrepatriated profits due to the benefits of deferral) and implement immediate taxation of GILTI income. However, without the new lower rates (and the GILTI deduction), the new U.S. minimum tax on foreign source income would not have been feasible. The upshot here is that minimum taxes are not enough - countries also must coordinate, or at least avoid sharp divergence of tax rates, as well as other aspects of corporate taxation. Susan Morse provides an extensive discussion of the coordination needed for minimum taxes. ${ }^{20}$

From this perspective, the U.S. prior to 2017 had a worldwide system that putatively aspired to a minimum tax (the full U.S. tax rate) but was deficient in many regards, particularly because of allowing deferral. This complex arrangement represented our political compromise, forged over the years, between a tax system based on capital export neutrality - which would tax domestic and foreign income at the same rate-and one with lower taxes on foreign source income in light of international tax competition from countries with lower tax rates. With the passage of the TCJA and the new international tax provisions, we tilted the playing field a bit more towards lower rates on foreign source income, conceding to the demand to match lower rates abroad and conform to international practice with a (partial) exemption of dividends from subsidiaries.

In order to preserve revenue and offset concerns about capital flight, as part of the new compromise system, we put in place a new unilateral minimum tax, although one not without controversial and complex provisions. ${ }^{21}$ Our new minimum tax was thus part of the complex tradeoffs necessary for the U.S. to meet foreign competition but not leave foreign income untaxed. It had its own domestic rationale, and the policy was not tied to a vision of multilateral tax coordination. And while it had minimum tax aspects, GILTI may also have simply constituted an effort to balance the taxation of domestic and foreign source income, tilting, as ever, toward lowering tax rates on foreign source income.

If other major countries stumbled to their own form of a unilateral GILTI or minimum tax there could be some international benefits. It would help clamp down on the diversion of profits to tax havens, as profits would eventually be taxed somewhere. Indeed, the U.S. could be a model or at least a starting place for other systems.

\footnotetext{
${ }^{19}$ For a discussion of GILTI, see supra note 3. For a succinct non-technical overview of the expense allocation issue, see Kyle Pomerlau, What's Up with Being GILTI?, TAX Found. (Mar. 14, 2019), https://taxfoundation.org/gilti-2019/ [https://perma.cc/69VZ-GTC2].

${ }^{20}$ See Morse, supra note 3.

${ }^{21}$ See Martin A. Sullivan, A New GILTI Spreadsheet for Policy and Planning, TAX Notes (July 29, 2019), https://www.taxnotes.com/featured-analysis/economic-analysis-new-gilti-spreadsheet-policy-andplanning/2019/07/26/29s4v [https://perma.cc/3KKV-UYN5].
} 
But it is not clear what a full multilateral agreement, with all its constraints on individual country tax policies, would additionally accomplish. A full international tax agreement would either require the unlikely full synchronization of tax bases across countries, including for example agreement over the extent of accelerated depreciation, or an agreed upon non-tax global financial accounting standard - an issue I address later in this Article. Of course, the process of international dialogue itself might pressure some countries who would not otherwise have the will or interest to change their tax systems. But that same type of international pressure could be applied to direct measures to curb profit shifting to tax havens, as the original BEPS project intended, without the heavyhanded apparatus of a global minimum tax that would impinge on tax sovereignty. ${ }^{22}$ Martin Sullivan suggests that we can accomplish most of our domestic goals through a second round of international tax simplification that would avoid the need to define GILTI as the excess over the 10\% return on invested assets (called Qualified Business Asset Investment or "QBAI") and simply impose a low tax rate on foreign source income. Sullivan opines:

Would it be such a terribly uncompetitive outcome for U.S. multinationals if the second round of international tax reform adopted a modest minimum tax on all foreign profits? The rate could be in the neighborhood of $10 \%$ ... Yes, this would be a floor on the overall rate of foreign tax to limit the incentive to move investment offshore. It could do that with no diminution of its role as an anti-abuse measure. ${ }^{23}$

Sullivan's suggestion mirrors the argument being made here that actions taken unilaterally to protect the tax base and avoid capital flight can also assist in curbing excessive profit shifting, without the recourse to a new global system of minimum taxes. Again, we should see this as a balancing of conflicting U.S. objectives of raising revenue, avoiding capital flight, and preserving a competitive framework for U.S.-based multinationals. One solution has the form of a convenient, low minimum tax on foreign source income, but this is far from justifying a multilateral system of minimum taxes. Indeed, this rationale for a unilateral minimum tax is silent on the perceived need to coordinate tax rates among countries to avoid what some might deem excessive tax competition.

Unilateral minimum taxes can be seen in this context as combating a defect in our tax system - the well-known and inherent difficulties in using arms-length pricing methods to police the income of intangible assets. This is not the only source of profits shifted to tax havens, but it is one that is conceptually intractable. ${ }^{24}$ As such, it provides a rough and ready method to deal with a persistent and largely unresolvable tax problem. Using unilateral minimum taxes in this manner would qualify as a minimal use of a minimum tax.

${ }^{22}$ For details on the OECD BEPS project, see Organisation for Economic Co-operation and Development [OECD], International Collaboration to End Tax Avoidance, https://www.oecd.org/tax/beps/ [https://perma.cc/6VQG-4SD9].

${ }^{23}$ Sullivan, supra note 21.

${ }^{24}$ See Jane Gravelle, Cong. Rsch. SERV., R40623, Tax Havens: International TAX Avoidance (2015) for a discussion of mechanisms to shift reported income to tax havens and intangible assets. For a contrary perspective, see Lorraine Eden, The Arm's Length Standard Is Not the Problem, 48 TAx MGMT. INT'L J. 10 (2019). 


\section{B. The Problem of Zero Tax Payments}

Behavioral economists have documented that individuals are extremely sensitive to "zeros" in economic transactions. ${ }^{25}$ Consumer behavior appears discontinuous with respect to very low prices for goods versus "free" goods. Goods which are advertised as free experience much higher demand than do goods with a price, even if the price is only nominal.

Zeros in taxation also appear to have great resonance in the public. The birth of the original AMT in the United States arose from the January 1969 testimony of Treasury Secretary Joseph W. Barr. Barr served at the very end of President Johnson's administration for just 28 days, but his testimony three days before President Nixon's inauguration had great political impact.

"Mr. Chairman and members of the Joint Economic Committee, I will hazard a guess that there is going to be a taxpayer revolt over the income taxes in this country unless we move in this area. Now, the revolt is not going to come from the poor. They do not pay very much in taxes. The revolt is going to come from the middle class. It is going to come from those people with incomes from $\$ 7,000$ to $\$ 20,000$ who pay every nickel of taxes at the going rate. They do not have the loopholes and the gimmicks to resort to, Mr. Chairman. However, when these people see, as I see, that in the year 1967, there were 155 tax returns in this country with incomes of over $\$ 200,000$ a year and 21 returns with incomes of over a million dollars for the year on which the "taxpayers" paid the U.S. Government not 1 cent of income taxes, I think those people are going to say it is time to do something about it and I concur." 26

This testimony created great political controversy and had a large impact. According to Len Burman, "in 1969, members of Congress received more constituent letters about the 155 taxpayers than about the Vietnam war." 27 As I discuss below, Congress adopted the first minimum tax provisions in that year.

There is also strong evidence that zero tax payments for corporate entities matter. Think tanks, such as the Institute on Taxation and Economic Policy, regularly publish studies based on accounting data that demonstrate that many corporations do not report paying any U.S. federal taxes. ${ }^{28}$ These studies are then regularly and widely picked up by the press, which sometimes even try to explain why particular companies paid zero taxes. ${ }^{29}$ This has been a perennial feature of American political discourse. Birnbaum and Murray describe the public outcry following a Citizens for Tax Justice study by Robert McIntyre

25 See Dan Ariely, Predictably Irrational 55-74 (2008).

${ }^{26}$ The 1969 Econ. Rep. of the President, Hearing Before the Joint Econ. Comm. of the Cong., 91st Cong. 5-6 (1969) (statement of Joseph W. Barr, Treasury Secretary).

${ }^{27}$ Leonard E. Burman, William G. Gale \& Jeffrey Rohaly, The Expanding Reach of the Alternative Minimum Tax, 17 J. ECON. PERSP. 173 (2003).

${ }^{28}$ See e.g. Matthew Gardner \& Steve Wamhoff, Corporate Tax Avoidance Remains Rampant Under New Tax Law, INST. ON TAX'N AND ECON. POL'Y (Apr. 11, 2019), https://itep.org/notadime/ [https://perma.cc/DL5K-43RQ].

${ }^{29}$ For an informative popular discussion, see Matthew Yglesias, Amazon's \$0 Corporate Tax Bill Last Year Explained, Vox (Feb. 20, 2019), https://www.vox.com/2019/2/20/18231742/amazon-federal-taxeszero-corporate-income [https://perma.cc/5K76-8JC8]. 
in 1984, which found that 128 out of the 250 largest corporations paid no federal income taxes for at least one year between 1981 and $1983 .{ }^{30}$

Experimental evidence also shows a deep sensitivity to corporations not paying taxes. One study compared public reaction to two investment programs - one with direct subsidies to corporations for investment and one using tax credits. ${ }^{31}$ If corporations paid positive amounts in taxes, the reaction of respondents in the survey was to treat the two programs (direct subsidy and investment credit) as roughly equivalent. But when the tax credits netted corporate tax liability to zero, then the subsidy program was greatly preferred.

This experimental result is an illustration of the "entity" phenomenon, which suggests that the public perception is that entities that are subject to taxes have a normative obligation to pay taxes. This applies especially to corporations, even though, as economists stress, corporations themselves do not "pay" taxes in terms of bearing an economic burden. Shareholders, workers, consumers, or other owners of capital bear the economic burden of taxes levied on corporations. But the ultimate incidence of corporate taxes does matter for public reaction.

The public does seem to hold an alternative view of corporate taxation that emphasizes the idea that the corporation itself should be paying tax aside from any payments of its shareholders. This is known as the "entity view" of corporate taxation as opposed to the "aggregative view" that sees the corporation as purely a conduit for shareholders. The entity view was initially developed in the late 19th and 20th centuries as large corporations became dominant forces in the economy. As Marjorie Kornhauser emphasized, one of the rationales for the original 1909 corporate income tax was to regulate the corporation while, in a related vein, Reuven Avi-Yonah suggested that the corporate tax was a method to contain corporate power by explicitly reducing corporate profits. ${ }^{32}$

Related to these discussions are the deeper issues of whether corporations are really "persons" and, if so, whether they are "artificial" or "natural" persons. Despite some resistance to this notion in casual opinion, it has been long established in United States law that corporations are "persons" in the sense that they can write and execute contracts and be held responsible for their actions. ${ }^{33}$ As Adam Winkler documents, U.S. courts have at times used both aggregative and entity views as they developed evolving doctrines of corporate rights. ${ }^{34}$ In the philosophical literature, the reality of group agency is also well established-groups can be seen to have their own goals and purposes, which can be encouraged or thwarted by public policies. ${ }^{35}$ Psychologists have also explored the contours of perceptions of agency and moral responsibility for corporations versus individuals. ${ }^{36}$

${ }^{30}$ See JefFery Birnbaum \& Alan Murray, Showdown at Gucci Gulch 38-39 (1987).

${ }^{31}$ See Steven Sheffrin, Perceptions of Fairness in the Crucible of Tax Policy, in TAX Progressivity AND INCOME INEQUALITY 325-327 (Joel Slemrod ed., 1993).

${ }^{32}$ See Marjorie E. Kornhauser, Corporate Regulation and the Origins of the Corporate Income Tax, 66 InD. L.J. 53 (1990); Reuven S. Avi-Yonah, Corporations, Society, and the State: A Defense of the Corporate Tax, 90 VA. L. REV. 1193 (2004).

${ }^{33}$ See Morton J. Horwitz, Santa Clara Revisited: The Development of Corporate Theory, W. VA. L. REV. 173 (1986).

34 See Adam Winkler, We the Corporations: How American Businesses Won Their Civil RigHTS (2018).

35 See Christian List \& Philip Pettit, Group Agency: The Possibility, Design, and Status of Corporate Agents (2011).

${ }^{36}$ See Mark Plitt, Ricky R. Savjani, \& David M. Eagleman, Are Corporations People Too? The Neural Correlates of Moral Judgments About Companies and Individuals, 10 SoC. NeURosCIENCE at 113 
With the entity view, corporations paying zero tax can be seen as broadly similar to nonpayment of taxes by individuals or as a moral failing.

Granted that there is visible public angst in the presence of zero tax payments for taxpayers who presumably have positive economic income, are explicit minimum taxes required in order to ease this political tension? There are at least two reasons to suggest that there may be political alternatives to minimum taxes: alternative presentations of taxpayer data and alternative tax strategies to directly attack the problems causing the zero taxes.

In late December 2019, Royal Dutch Shell made public its revenue, profit, and taxes paid in 98 countries around the globe. ${ }^{37}$ As of 2017, this data is now required to be reported for tax authorities for major companies based on policies agreed upon at the OECD. ${ }^{38}$ Royal Dutch Shell now voluntarily made these public. As the Wall Street Journal noted, it did attract adverse publicity in the UK (its tax home) because it paid no taxes due to loss carryforwards. Nonetheless, it could point to the substantial amount of taxes paid around the globe. This public reporting strategy can potentially turn the debate about corporate taxation in a new direction. Instead of asking whether Royal Dutch Shell "pays taxes," the debate turns to whom the taxes are paid. This may prompt debates about transfer pricing or related tax strategies, but these are practical rather than moral arguments. Royal Dutch Shell may be paying too much in Singapore and the United States and not enough in the UK, but it is difficult to say that as a worldwide company it is not paying taxes at all.

When the original studies of non-tax paying corporations were first published in the 1980s, the focus of most Americans was on domestic matters. But with the advent of rapid globalization and the emergence of non-oil corporations into world leaders, the political focus and landscape has changed. Apple, Google, and Starbucks may be criticized in Europe for minimal tax payments to EU countries, but they paid U.S. tax. Amazon is an exception, paying no U.S. federal taxes in 2018 due to loss carryforwards, research and development tax credits, expensing of investment, and stock-based employee compensation. However, even they reported $\$ 2.6$ billion in corporate taxes worldwide. ${ }^{39}$ Reporting this information in its totality may raise questions about the structure of the U.S. tax system and provisions in the tax code, but again it is hard to claim that Amazon is an immoral entity not paying taxes at all. Whether the public will be satisfied if a corporation pays taxes somewhere is a subject that has not really been studied, but it clearly changes the terms of the debate.

Alternative tax strategies other than minimum taxes can also deal with the problem of zero tax payments. The best way to see this is to consider the changes to the alternative minimum tax after the passage of the TCJA. As I noted above, the TCJA vastly reduced the number of taxpayers subject to the AMT, so that the number now totals approximately

(2015); Adam Waytz \& Liane Young, The Group-Member Mind Trade-Off: Attributing Mind to Group Versus Group Members, 23 PsychOL. SCI. at 77 (2012).

${ }^{37}$ Rochelle Toplensky, The Beginning of the End of Tax Secrecy, WaLl ST. J. (Dec. 20, 2019), https://www.wsj.com/articles/the-beginning-of-the-end-of-tax-secrecy-11576837708 [https://perma.cc/GQ9Q-XTVD].

${ }^{38}$ See Martin Sullivan, Are Country-By-Country Reports Worthless?, 166 TAX NotES FED. 198 (Jan. 13, 2020) (explaining the weaknesses in these required reports).

${ }^{39}$ See Andrew Davis, Why Amazon Paid No 2018 US Federal Income Tax, CNBC (Apr. 4, 2019), https://www.cnbc.com/2019/04/03/why-amazon-paid-no-federal-income-tax.html [https://perma.cc/R2HV32RS]. 
only 200,000, down from approximately 5 million. Yet, the explanation of the Joint Committee of Taxation for the changes to the AMT seem on the surface rather modest. ${ }^{40}$ According to this explanation, the threshold amount was increased, the phaseout level was increased, and the amounts are now indexed for inflation. But there were other more important reasons why the number of AMT taxpayers has fallen. Specifically, the TCJA eliminated the personal exemption and placed a limit of $\$ 10,000$ on total state and local tax deductions. The combination of these deductions had previously pushed many taxpayers in high-tax states into the AMT.

The taxpayers remaining under the AMT are still subject to a number of provisions, including limits on depreciation and amortization and, perhaps most significantly, inclusion of the "spread" on incentive stock options when they are exercised. ${ }^{41}$ Individual taxpayers are also subject to limitations on the use of net operating losses (NOLs) and are not allowed to carry back losses. ${ }^{42}$ Although detailed data on the nature of current AMT taxpayers is not yet available, there were some reports that many the taxpayers falling under the new AMT are there due to the incentive stock option rules. ${ }^{43}$

If taxpayers now fall under the AMT for only a selected number of tax preferences, there is an argument for either tackling these preferences directly by strictly limiting them or partially limiting them using an "add-on" minimum tax. An add-on minimum taxwhich was the original design for the current AMT_-simply adds back some fraction of tax preferences, subjects them to a specified tax rate and then adds the results to regular tax liability. They can be designed in various ways to apply strictly to taxpayers with higher economic income by providing exemption levels, but they are all specific to a certain list of tax preferences. These could be structured in several different ways: under one model, each tax preference could have its own exemption level and under a second model, there could be an exemption level for all tax preferences taken together. For an example of the former, the spread on incentive tax options could be included at a specified rate (or according to a rate schedule based on some expanded measure of economic income) above a given exemption level.

What would be the advantages and disadvantages of this approach? One immediate advantage it that it would finally dismantle the AMT, which is scheduled to return in 2026. Depending on the other tax changes that are legislated at that time, we could be in a situation where upper-middle class taxpayers are drawn back into paying the AMT. More directly, this approach would focus attention on the specific tax provisions that may or may not need reform. Of course, this could be a political disadvantage as it does require politicians to single out certain tax preferences for reduction. But if the number of tax preferences is relatively small, this may not be a major political economy concern. ${ }^{44}$

\footnotetext{
${ }^{40}$ Staff of Joint Comm. on TaX’n, 115 th Congress, Gen. Explanation of Pub. Law 115-97, $97-$ 98 (Joint Comm. Print 2018)

${ }^{41}$ The spread is the difference between the market price of the stock and the price at which the option allowed one to buy the stock.

${ }^{42}$ As noted above, the CARES act temporarily suspended some limitations on NOLs and the use of carrybacks.

${ }^{43}$ See Matthew Frankel, Your 2020 Guide to the Alternative Minimum Tax, The Motley Fool (Dec. 17, 2019), https://www.fool.com/taxes/2019/12/17/your-2020-guide-to-the-alternative-minimum-tax.aspx [https://perma.cc/F4KN-PK89].

${ }^{44}$ See, e.g., Daniel Shaviro, Perception, Reality, and Strategy: The New Alternative Minimum Tax, 66 TAXES 91 (1988) (discussing some political economy issues).
} 
It is important to keep in mind that the NOL limitations generally prevent taxpayers from totally zeroing out their tax liabilities. ${ }^{45}$ Coupled with other tax code provisions such as the passive loss rules, we no longer have the broad spectrum of taxpayers with large economic income paying no taxes. For the few exceptions that might occur-such as someone subsisting totally on interest on private tax-exempt bonds (where even then they pay an implicit tax) - we could design specific provisions to deal with these cases without creating an entirely new parallel tax system. Again, we can treat tax preferences separately or as a group. If there were separate exemption levels for each tax preference, one could imagine a few situations where taxpayers employ a full range of tax preference strategies, manage to fall under the exemption levels for all of them, and in total reduce their taxable income close to zero. That would be a prima facie case where a limitation on total tax preferences might be more effective in preventing this situation from occurring. But whether it is worth the extra complication would depend on how frequently this pattern would occur.

Once we move away from taxpayers with zero tax payments, we also must ask whether provisions such as the AMT which try to limit differences in effective tax rates for taxpayers (based on economic income) are worth the effort. There are clearly more glaring holes in the tax system than taxpayers who enjoy tax-exempt interest on private activity bonds. Wealthy individuals who only minimally realize income from sales of stock and can live off lines of credit - without direct tax consequences - are a much more serious failure of our tax system. ${ }^{46}$ This is not to say that we may not want some add-on tax provisions for tax-exempt interest or incentive stock options, but we need to keep in mind the relative benefits of complicating our tax system for marginal gains in taxpayer equity.

\section{Efficiency Arguments for Minimum Taxes}

At first glance, making efficiency arguments in favor of minimum taxes appears to be a daunting task, at least in the domestic context. Typically, minimum taxes have had the following structure: first, legislatures decide that taxpayers should be entitled to take certain deductions to aid legitimate social goals, for example, for state and local taxes or accelerated depreciation. Second, minimum taxes then take these deductions away if the taxpayer's income is reduced "too much" by the allowed deductions.

The operation of minimum taxes in this manner raises immediate questions. If policymakers believe it is beneficial to subsidize state and local governments through deductions on individual income taxes, why should it be arbitrarily limited if a taxpayer either takes too many of these deductions or if their cumulative deductions from other items are too high? The issue with respect to investment income is even more stark. Suppose a legislature believed that there was a strong efficiency case for subsidizing investment through accelerated deprecations. If we bar a firm or individual from taking full advantage of these subsidies because their resulting income would be too low, we are then removing what was deemed to be a beneficial subsidy in the first place. Moreover, we create economic inefficiencies (as well as horizontal inequities) as two taxpayers with identical investment opportunities will face different after-tax benefits to their investments if one is subject to the minimum tax and the other is not. ${ }^{47}$

\footnotetext{
${ }^{45}$ NOL deductions after 2017 are limited to 80 percent of taxable income (before the NOLs are included) for that year. However, this provision has been temporarily suspended by the CARES act.

${ }^{46}$ See Edward J. McCaffery, The Death of the Income Tax (or, the Rise of America's Universal Wage Tax), 95 IND. L.J. 1233, 1264 (2020) (reporting that Larry Ellison has a \$10 billion line of credit).

${ }^{47}$ This can also create clientele effects where taxpayers purchase assets based on their own tax status.
} 
What then could be the efficiency rationales for minimum taxes? There are two types of efficiency arguments that can be put forward. First, policymakers cannot target their subsidies with full accuracy and a minimum tax can serve as a partial antidote to this failure in targeting. Second, there are inherent flaws in the operation of our traditional tax instruments relative to ideal taxes. For example, if we tax capital gains only when they are realized as opposed to when they accrue, we set the stage for complex tax shelters based on borrowing against appreciated assets. If we cannot avoid the realization requirement, then alternative tax instruments may be necessary to achieve our tax policy goals.

With respect to targeting, consider the following example. The government wishes to subsidize productive firms with investment credits for investment. However, there are two types of firms - productive firms and unproductive firms. Unproductive firms will show perennial losses. Most productive firms will have positive ongoing taxable income but some, for example start-up firms, will not. Even productive firms can have some bad luck and resulting losses for some period. If all firms were productive, we would want the investment credits to be fully refundable and not require the credit to be taken against positive taxable income. Refundable credits, of course, would mean that some firms would effectively have negative taxes.

What can policy makers do in this case? Enforcing a minimum tax at zero (no refundability or allowance for carrybacks) creates a trade-off. If they permit refundable credits, they will subsidize unprofitable firms. But if they do not, they will miss the opportunity to subsidize efficient firms who are temporarily unprofitable. One solution would be to impose a minimum tax of zero by requiring the investment credits to be taken against taxable income, but to allow the credits to be carried forward, with interest. If productive firms based their decisions on present values - and were not liquidityconstrained by cash flow - this would solve the design problem for policy makers in this simple setting. Alan Auerbach analyzed a dynamic framework without interest on carryforwards and found that the ability to design a system to encourage only productive firms was limited. ${ }^{48}$

Minimum taxes could also in principle be used to offset flaws in our tax instruments. David Gamage makes a strong case that when individual taxes do not fully measure the tax base, there may be a case for using multiple instruments to achieve tax policy goals. ${ }^{49}$ For example, faced with the practical limits of a realization requirement, combing a consumption tax with an income tax can ensure that even those taxpayers who are taking advantage of realization requirements to shelter income will at least pay some tax when they consume. David Schizer makes a related point with respect to whether to tax capital income at the corporate or shareholder level. ${ }^{50}$ As taxes on either shareholders or corporations rise, so do the incentives for tax avoidance. According to Schizer, we should avoid relying too much on a single tax instrument as that will give rise to avoidance costs for the economy; it would be better to use a combination of taxes to minimize avoidance costs, even if that creates some additional inefficiencies.

Minimum taxes can also be a potential remedy when a tax avoidance strategy becomes all too evident but the normal tools to tackle the strategy are not effective. The

(1986).

${ }^{48}$ See Alan Auerbach, The Dynamic Effects of Tax Law Asymmetries, 53 ReV. Econ. Stud. 205

49 See David Gamage, The Case for Taxing (All of) Labor Income, Consumption, Capital Income and Wealth, 68 TAX L.R. 355 (2005).

${ }^{50}$ See David M. Schizer, Between Scylla and Charybdis: Taxing Corporations, Shareholders (Or Both), 16 CoLuM. L.R. 1850 (2016). 
entire BEPS program of the OECD was predicated on the inability of countries to use their normal tax tools - transfer pricing, controlled foreign corporation (CFC) rules and othersto address the tax base erosion problem. While the BEPS project also made other recommendations to improve the operation of tax systems, for example, avoiding mismatches of business structures that permit tax avoidance, the OECD was led, as discussed above, to at least consider minimum taxes as a solution to their collective problem. As I have argued, however, a global minimum tax is itself problematic - but the origins of such an idea are understandable because of other deficiencies in the international tax system.

The state corporation income tax provides another example. States are required to apportion income of businesses that operate in multiple states. However, they approach the apportionment process in several different ways, including through the use of different apportionment formulas. Aside from any differences in apportionment formulas, states also differ in the business entities that they apportion. Twenty-two states tax corporations on an entity-by-entity basis, while the others (plus the District of Columbia) base their apportionment on a combined return, which apportions the income of a unitary group. ${ }^{51}$ While precisely defining a unitary group is challenging, it typically requires ownership thresholds above $50 \%$ and that the combined corporations (and partnerships) are generally in similar lines of business. In a combined report, payments from one member of the group to another are netted out, so that the income of the combined group does not depend, for example, on a payment from one subsidiary to another for the use of intangible property. In an entity-by-entity or single entity system, such payments do matter, particularly if the payor and payee subsidiaries reside in different states. For these reasons, most tax experts believe that single entity states face more potential problems with corporate tax avoidance than do combined reporting states.

Now, the states with corporate taxes that have not adopted combined reporting (mostly in the southern United States) all have their unique reasons for not doing so. Perhaps there is a coordination problem in that being a first mover would make them stand out from their neighbors. There are strong political pressures from the business community not to adopt combined reporting and the states may see this as an economic development matter on which they cannot afford to stand out. Finally, they may believe that entity-byentity taxation is better on the merits. ${ }^{52}$ Whatever the precise reason, these states do subject themselves to the additional risks of profit-shifting to other states.

One potential response to this risk would be to impose another tax on corporations that cannot be as easily shifted. In fact, many of the single entity states in addition to their state corporate income tax also have a corporate franchise or net worth tax. Of the sixteen states that have franchise taxes, nine of them are single entity states. The franchise tax in these states could be a vehicle to ensure that they receive some revenue from multistate corporations in the face of potential profit shifting. Later in this Article, I discuss a more concrete proposal to have the franchise tax serve as an alternative minimum tax for corporations.

${ }^{51}$ See e.g., Center on Budget and Policy Priorities, 28 States Plus D.C Require Combined Reporting for the State Corporate Income Tax (2018), https://www.cbpp.org/27-states-plus-dc-require-combinedreporting-for-the-state-corporate-income-tax [https://perma.cc/9FJF-FMLP].

52 See La. Tax Inst., Report to the Legislature on Corporate Income Tax Combined REPORTING, 2019-001 (2019), http://revenue.louisiana.gov/Miscellaneous/TXI\%202019-001\%20MUCR \%20Report.pdf [https://perma.cc/2LJC-M76W]. 
III.

\section{TAX DESIGN ISSUES}

In this section I address some issues that have arisen with the individual and corporate alternative minimum taxes. I highlight two themes. First, both taxes evolved over time away from their original goals, which eventually led to either their effective or actual demise. I try to understand the features of the taxes which led to this evolution. Second, I explore the idea that has been recently resurrected of using non-tax bases-for example, financial accounting measures - to serve as the basis for alternative taxes.

A. Policy Drift and the Individual and Corporate Alternative Minimum Taxes

During the first part of the decade of the 2000s, the number of taxpayers subject to the alternative minimum tax rose from approximately 1 million in 1999 to over 4 million by $2005 .{ }^{53}$ Projections made by tax experts in 2003 and 2005 predicted that without changes to the AMT rules, over 30 million taxpayers would be subject to the AMT by $2010 .{ }^{54}$ In fact, though, the number of AMT taxpayers stabilized in the 4-5 million range until the sharp curtailment of the AMT in 2018.

The initial increase in the projected rise in the number of AMT taxpayers can be attributed to the intricate interactions between the regular tax system and the AMT. Taxpayers first calculate their regular tax liability, then make an alternative calculation under the AMT disallowing certain tax preferences and calculating their AMT amount under the exemption levels, rules for phaseouts of the exemptions, and the tax rates under the AMT. If the calculated AMT amount is higher than their regular tax liability, taxpayers pay the difference as an additional AMT. Aside from the AMT tax preferences, the base and rates of the regular tax and the exemption level, phaseout and rates of the AMT are primary determinants of total tax liability and the number of taxpayers subject to the AMT.

When significant changes were made to the regular tax system in 2001, 2003, and 2004, all of which lowered tax liabilities, there necessarily would have been an increase in AMT liability unless the key tax parameters of the AMT were changed as well. While there were some minor changes to AMT exemption levels that accompanied these tax bills, they were not enough to prevent the number of AMT taxpayers from increasing by a factor of four over this period. The additional revenue from the AMT would have been incorporated into the revenue projections for the tax bills so that the tax committees and presumably some members of Congress would have been aware of these changes.

While tax brackets under the regular income tax were indexed for inflation, the brackets under the AMT were not. This was one of the factors leading to the projection of further sharp increases in the number of AMT taxpayers. The other reason was the cumulative effect of the tax reductions from the 2001, 2003, and 2004 acts, which were themselves phased in. The projected increase to over 30 million taxpayers subject to the intricacies of the AMT by 2010 was deemed an "AMT crisis." 55

Rather than tackle this issue directly with a reform that more closely tied the base of the regular income tax to the base of the AMT, Congress instead enacted a yearly set of

${ }^{53}$ See Tax Policy Center, What is the AMT? (May 2020), https://www.taxpolicycenter.org/briefingbook/what-amt [https://perma.cc/AEY8-R85V].

${ }^{54}$ See Burman et al., supra note 27, at 173; Patrick Fleenor \& Andrew Chamberlin, Backgrounder on the Individual Alternative Minimum Tax (AMT), TAX Found. (May 24, 2005), https://taxfoundation.org/backgrounder-individual-alternative-minimum-tax-amt/ [https://perma.cc/ET29X99Z].

${ }^{55}$ Fleenor \& Chamberlin, supra note 54. 
what came to be known as "patches" that increased the exemption levels to keep the number of AMT taxpayers approximately constant. ${ }^{56}$ It was not until the American Taxpayer Relief Act of 2012 that the exemption levels and phaseouts were indexed for inflation. This bill also raised taxes on higher income individuals, and the joint effect of these changes was to stabilize the number of AMT taxpayers until they dropped sharply in 2018 with the TCJA changes.

The type of instability we witnessed in the AMT in the first decade of the 2000s is to be expected when an alternative minimum tax starts from the same base as the regular income tax. When Congress enacts tax legislation, there is often an overriding vision. The 2001 and 2003 tax bills were explicitly focused on promoting economic growth (the Economic Growth and Tax Relief Reconciliation Act of 2001 and the Jobs and Growth Tax Relief Reconciliation Act of 2003), while the 2004 tax legislation suggested relief for families (the Working Families Tax Relief Act of 2004). Legislators, as well as the media and constituents, will naturally focus their attention on the explicit provisions in the legislation. It would be unnatural for them to focus as much attention on the AMT.

The one exception might be if there were a desirable tax provision in the new legislation that would become ineffective because of the AMT rules. Aside from that case, legislators would typically ignore the AMT or at best make minor adjustments to it. And indeed, if the new tax bill lowers tax liabilities, there is an incentive to ignore increases under the AMT, as making offsetting changes to the AMT would increase revenue loss from the proposed legislation. It would be more politically advantageous to use the extra revenue gained under the AMT to provide more visible tax benefits to constituents. Moreover, to the extent that the AMT would increase the tax liabilities of upper-middle class individuals, it would improve the appearance of the tax distribution tables. It took more than a decade of instability and ad hoc changes to enact inflation indexing for the AMT.

The corporate AMT followed a different path in the 2000s, but also exhibited tensions from being closely tied to the regular corporate income tax. The corporate alternative minimum tax operated on similar principles to the individual AMT but was considerably more complicated. In calculating an alternative tax liability, there were two principal adjustments that constituted roughly all of the difference between the regular and corporate tax base. ${ }^{57}$ The first was limits on deductions for depreciation that corporations could utilize in the current year and the second (after 1990) was an adjusted current earnings provision based on the "earnings and profits" provisions of the tax code, which are used in calculating dividend distributions. Because these were effectively timing adjustments-limiting, for example, accelerated deprecations but eventually allowing for assets to be fully depreciated - the corporate AMT allowed credits for prior tax payments so that there would be full basis recovery. Thus, the corporate AMT effectively accelerated tax payments, thereby typically imposing a higher cost of capital for firms subject to it. Lyon discusses several economic distortions arising from the timing provisions of the AMT and the loss of tax credits. ${ }^{58}$

56 Cong. Budget Office, The Individual Alternative Minimum Tax (2010) https://www.cbo.gov/sites/default/files/111 th-congress-2009-2010/reports/01-15-amtbrief.pdf [perma.cc/CB8L-9NAG].

${ }^{57}$ LYON, supra note 2, at 15-47.

${ }^{58} \mathrm{Id}$. at $77-81$. 
The tax legislation in the early 2000s, however, was designed to stimulate investment and provide "bonus depreciation" or a form of accelerated depreciation. It would defeat the purposes of the legislation to award bonus depreciation but then remove it through the corporate AMT. Large corporate taxpayers, who were the ones primarily subject to the corporate AMT, and their representatives made these concerns known in the legislative process. Unlike the individual AMT provisions, the adverse consequences from the corporate AMT could not easily hide in the background away from the light of interested taxpayers. Consequently, bonus depreciation was allowed under the corporate AMT and not counted as a preference item.

The result of removing bonus depreciation as an AMT preference significantly reduced the revenues from the corporate AMT. Based on statistics of income data on AMT tax payments net of AMT credits, the ratio of corporate AMT payments to regular corporate income tax liability decreased from about $1.7 \%$ in 1996 and 1997 to $0.8 \%$ in $2006 .{ }^{59}$ It remained roughly at this level through 2013, when it was at $0.9 \%$. By the time of the passage of TCJA, the Joint Committee on Taxation estimated that eliminating the corporate AMT would lead only to a $\$ 40$ billion revenue loss over a 10 -year period. ${ }^{60}$ Although the Senate did try to maintain the corporate AMT for revenue purposes, the relatively small amount of revenue involved and the prospect that some firms would not be able to take research and development credits led ultimately to the corporate AMT being eliminated in the conference. ${ }^{61}$

Our experience with the corporate AMT in the 2000s is another example of how tying a minimum tax closely to an existing tax base can cause complexity and thwart legislative purposes. While sophisticated corporate taxpayers in the early 2000 s were able to ensure that some benefits of investment incentives were still provided to them, it took fifteen years before an eviscerated corporate AMT was removed from the law.

While I have argued that minimum taxes that rely on the same underlying tax base tend to thwart legislative purposes, as we saw with the bonus depreciation example, it is possible to synchronize changes between the regular tax and the AMT. But in less salient settings, it is certainly possible that adjustments to the regular tax could be offset by increased liability under the AMT.

\section{B. Accounting Bases for Alternative Taxes}

If tying an alternative tax too closely to the regular tax causes problems, what about using an alternative non-tax base for a minimum tax? About fifteen years ago, there was a flurry of interest in using income as reported on financial statements to revamp the corporate tax. ${ }^{62}$ More recently, in the OECD's Pillar 1 proposal designed to reallocate taxing rights, there was a suggestion that the starting place should be the consolidated

${ }^{59}$ Calculations based on IRS statistics of income data. See I.R.S., SOI Tax Stats - Table 18 - Returns of Active Corporations (Jan. 30, 2020), https://www.irs.gov/statistics/soi-tax-stats-table-18-returns-of-activecorporations [https://perma.cc/T9C5-E6SC].

60 See Joint Comm. on Tax'N, 115Th Cong. JCX-67-17, Estimated Budget EfFects of the Conference Agreement for H.R.1, The "TAX Cuts And Jobs ACt" (Dec. 18, 2017).

61 See Neil Barr et al., DAVIS PoLK, Tax Reform and Transition (Dec. 3, 2017), https://www.taxreformandtransition.com/2017/12/last-minute-retention-of-corporate-amt-in-senate-tax-billhas-unintended-consequences/ [https://perma.cc/8YX2-4WGN] (showing the opposition to retaining the AMT).

${ }^{62}$ See generally Michele Hanlon \& Terry Shevlin, Book Tax Conformity for Corporate Income: An Introduction to the Issues, 19 TAX POL'Y ECON. (2005); John McClelland \& Lillian Mills, Weighing Benefits and Risks of Taxing Book Income, 32 Ins. TAX REV. 721 (2007). 
financial accounts based on the headquarters of large multinational firms. There was also a proposal from a 2020 presidential candidate for a supplemental tax based on financial accounting income. ${ }^{63}$

The response of tax and accounting experts to the original proposals was largely negative. While relying on financial accounting measures as a basis for corporate taxation had some advantages in terms of reducing compliance costs and possibly reducing profitshifting, the risks were a degradation of the financial information provided to shareholders and the public, and a keen recognition of the differing purposes of financial and accounting measures. As Hanlon and Shevlin wrote:

"Financial accounting income is intended to provide outside stakeholders (e.g., investors, creditors, regulators, etc.) with information about firm performance." In contrast, the objectives of the IRC are to provide a framework for efficient and equitable determination of tax liabilities and the subsequent collection of revenue, and to provide incentives for firms to engage in, or not engage in, particular activities, and to reward particular constituencies." 64

Hanlon and Shevlin also provided evidence that countries that moved to more closely align book and tax income saw less influence of financial reports on financial markets, suggesting that this linkage led to less informative financial accounting. They also emphasized that the differences between book and accounting measures-for example, in terms of depreciation deductions and bad debt expenses-were profound and inconsistent with the needs of the taxing authorities to maintain a robust tax base. ${ }^{65}$

In terms of minimum taxes, from 1987 to 1989, the alternative corporate minimum tax was partly calculated using financial measures, but that system was abandoned in 1990 and replaced with adjusted current earnings as one of the bases to calculate tax preferences. ${ }^{66}$ Ultimately, principles derived from the existing tax code were utilized to calculate tax preferences.

More generally, the issues I raised above about the need to synchronize the regular and alternative minimum taxes still apply and with more force. As I discussed with the alternative minimum taxes, if Congress wishes to provide incentives with accelerated depreciation or expensing as under the TCJA, the base for the alternative minimum tax will need to be adjusted to ensure that the incentives Congress wishes to apply have their intended impact. While Congress historically only made limited adjustments to the individual alternative minimum tax, in the corporate arena they were more sensitive to the need to synchronize the tax bases, for example, by allowing bonus depreciation under the corporate alternative minimum tax.

${ }^{63}$ See Mindy Herzfeld, Warren, the OECD, and Book-Tax Conformity, 165 TAx Notes Fed. 393 (Oct. 21, 2019). The OECD Pillar One proposal is primarily concerned with reallocating the tax base and suggest financial accounting as a starting point. See Organisation for Economic Co-operation and Development [OECD], Secretariat Proposal for a "Unified Approach" (Oct. 9, 2019), https://www.oecd.org/tax/beps/public-consultation-document-secretariat-proposal-unified-approach-pillarone.pdf [perma.cc/Z242-D9CC].

${ }^{64}$ Hanlon \& Shevlin, supra note 62, 104-05.

${ }^{65}$ Tax law often allows accelerated depreciation, but this is not recognized for book purposes. Financial accounting is more lenient than tax accounting with respect to when bad debt deductions are recognized. In the United States, large corporations are currently required to file Schedule M-3 to reconcile book and tax income, which may be useful to the IRS for auditing purposes.

${ }^{66}$ For an early discussion of the issues with this initial experiment, see Shaviro, supra note 44. 
Having both bases under Congressional control, therefore, is necessary to be consistent with its legislative intent. Delegating the content of an alternative base to a nongovernmental third party would defeat this purpose. As a practical matter, it would also be highly unlikely to survive any normal legislative process. Even if this delegation were initially to take place, based on experience it is likely that Congress would try to intervene in the accounting standards setting process. ${ }^{67}$

Herzfeld also highlights several different reasons why national governments, through their tax policy, may have different goals than financial accountants, which would inevitably lead to sharp tensions between measures of financial and taxable income. ${ }^{68}$ Governments may be interested in promoting growth (through accelerated depreciation), managing downturns (through increasing the usage of NOLs and carrybacks), encouraging innovation by not limiting credits such as those for research and development, and providing investment incentives in locales where firms might initially report losses. The national and international demand for these goals may rise and fall over time, but they are unlikely to disappear.

Since the mid-2000s, there have been more radical tax base changes both proposed and enacted by Congress. The destination cash flow tax was initially proposed by House Republicans, while the TCJA enacted expensing along with limits of interest deductibility. If anything, the conceptual distance between book and tax measures has increased as Congress has increasingly adopted more consumption tax principles in their actual or contemplated legislation. Book accounting measures would only be potentially comparable if the tax system were based on income tax principles. Once consumption tax principles take root, the conceptual distance between tax and book accounting measures becomes insurmountable.

\section{ONE EXAMPLE OF AN EFFICIENCY BASED AMT}

In this section, I provide an example of how restructuring a tax as a minimum tax can lead to an improvement in the tax structure of a state, moving in the direction of reform in a manner that may be politically feasible. The example is restructuring the franchise tax as an alternative minimum tax for the state corporate income tax in Louisiana.

First, some necessary background. The state of Louisiana imposes both a corporate income tax and a franchise tax. Corporations file a single return that includes both income and franchise taxes, and allowable credits can be taken against both taxes. The corporate income tax is based on the separate entity principle, where each corporation files a separate return and its income is apportioned separately. As I discussed above, twenty-two states use this method and it is heavily concentrated in the southern states. Louisiana is also one of the sixteen states that levy a general franchise tax or a tax levied on a base of a corporation's equity or sometimes capital. ${ }^{69}$ In determining the sixteen states, I exclude those that only levy franchise taxes on financial corporations (Michigan and Vermont), impose very minimal franchise fees (New Mexico), or use the term to refer to their corporate income tax (California).

Nine of the sixteen states that have a franchise tax are in the South - all those states also have single entity filing for corporate taxation. Some states, including Mississippi in

\footnotetext{
${ }^{67}$ See Hanlon \& Shevlin, supra note 62, at 113 (discussing controversies over stock options and other more recent examples).

${ }^{68}$ See Herzfeld, supra note 63.

${ }^{69}$ See Janelle Cammenga, Does Your State Levy a Capital Stock Tax? TAx Found. (Aug. 21, 2019) https://taxfoundation.org/state-capital-stock-tax-2019/ [perma.cc/BCJ9-NS36].
} 
the South, are in the process of phasing out their franchise tax. Nonetheless, the combination of single entity filing for corporation taxes and franchise taxes appear to be a robust combination in the southern states.

Louisiana imposes its franchise tax on a taxable base that includes issued and outstanding capital stock, surplus, and undivided profits. ${ }^{70}$ All of these terms are defined by Louisiana statutes, but the tax base can be construed as the amount paid for shares plus retained earnings. Debt was removed from the tax base in prior years, so effectively the franchise tax is a tax on equity capital. The top rates applied to the capital base are $\$ 1.50$ per $\$ 1,000$ up to $\$ 300,000$ and then $\$ 3.00$ per $\$ 1,000$ of taxable base above $\$ 300,000$. There is no cap on the total tax (as in seven other states) and it is levied separately and added to any corporate tax liability. Although the tax originally only applied to corporations, the law was changed in 2016 to include corporations that own property in the state either directly or indirectly through partnerships or joint ventures and to other entities that checked the box as corporations. The franchise tax is apportioned based on property and sales.

As a tax on equity capital that is paid regardless of profitability, it is naturally an unpopular tax. Tax reform groups have recommended repeal if alternative revenue sources can be found. The 2017 report of the Task Force for Structural Change in Budget and Tax Policy, a group appointed by the governor and legislature, was clear on its assessment of the franchise tax:

"The franchise tax is a tax on wealth and investment that represents the equity of a corporation. Investment supported by long-term debt is not subject to the corporate franchise tax. It is widely recognized as a complex and antiquated type of taxation that discourages investment, inhibits economic development, provides a disincentive to corporate headquarters operations and causes costly compliance and auditing problems."71

However, because of the potential loss in revenues, the Task Force recommended seeking strategies to eliminate or phase out the tax with other changes made to the tax system to preserve revenue neutrality.

To understand the revenue impact, staff at the Louisiana Department of Revenue provided data showing the effects of a repeal of the franchise tax on the total of corporate tax and franchise tax revenues, arrayed by the taxable base of the franchise tax. Table 1 below shows the impact of the repeal after all allowable credits that could be taken against the total tax liability under both taxes for tax year 2017.

${ }^{70}$ For background, see JAMES Richardson, STEVEn SHEFFrin \& JAMES Alm, ExPloring LongTERm SOlUTIONS FOR LOUISIANA's TAX SYSTEM (2018).

${ }^{71}$ See Task Force on Structural Changes in Budget and Tax Pol'y, Louisiana's Opportunity: Comprehensive Solutions for a Sustainable TaX and Spending Structure, La. Dep't of REVENUE 36 (2017), https://www.revenue.louisiana.gov/LawsAndPolicies/TaskForceOnStructuralChanges BudgetTaxPolicy [perma.cc/UTU5-A65R]. 
Table 1: Repeal of Franchise Tax

\begin{tabular}{|c|c|c|c|c|c|}
\hline $\begin{array}{l}\text { Taxable Base } \\
\text { Range }\end{array}$ & $\begin{array}{c}\text { Number } \\
\text { of } \\
\text { Returns }\end{array}$ & $\begin{array}{l}\text { Total After } \\
\text { Credits }\end{array}$ & $\begin{array}{c}\text { New Total } \\
\text { After } \\
\text { Credits }\end{array}$ & Difference & $\begin{array}{c}\text { Average } \\
\text { Difference }\end{array}$ \\
\hline Less than 0 & 17,759 & $11,317,022$ & $10,693,134$ & $-623,888$ & -35 \\
\hline $\mathbf{0}$ & 77,248 & $21,331,846$ & $21,215,175$ & $-116,672$ & -2 \\
\hline $1-25,000$ & 19,647 & $3,010,333$ & $2,782,549$ & $-227,784$ & -12 \\
\hline $25,001-100,000$ & 13,796 & $3,972,061$ & $2,940,232$ & $-1,031,828$ & -75 \\
\hline $100,001-500,000$ & 15,073 & $12,019,278$ & $6,844,953$ & $-5,174,325$ & -343 \\
\hline $\begin{array}{l}500,001- \\
1,000,000\end{array}$ & 4,339 & $77,703,477$ & $71,541,321$ & $-6,162,155$ & $-1,420$ \\
\hline $\begin{array}{l}1,000,001- \\
10,000,000\end{array}$ & 6,645 & $74,945,614$ & $29,284,395$ & $-45,661,219$ & $-6,872$ \\
\hline $\begin{array}{l}10,000,001- \\
50,000,000\end{array}$ & 1,327 & $110,744,136$ & $42,520,269$ & $-68,223,867$ & $-51,412$ \\
\hline $\begin{array}{l}50,000,001- \\
100,000,000\end{array}$ & 243 & $59,382,074$ & $20,776,308$ & $-38,605,766$ & $-158,871$ \\
\hline $\begin{array}{l}100,000,001- \\
500,000,000\end{array}$ & 193 & $145,410,704$ & $44,008,697$ & $-101,402,007$ & $-525,399$ \\
\hline $\begin{array}{l}500,000,001- \\
1,000,000,000\end{array}$ & 32 & $68,653,352$ & $14,233,062$ & $-54,420,290$ & $-1,700,634$ \\
\hline$>1,000,000,000$ & 19 & $82,694,996$ & $9,176,247$ & $-73,518,749$ & $-3,869,408$ \\
\hline Total & 156,321 & $671,184,893$ & $276,016,343$ & $-395,168,551$ & $-2,528$ \\
\hline
\end{tabular}

Source: Louisiana Department of Revenue, data for tax year $2017 .^{72}$

The table shows that in 2017 the total of corporation and franchise taxes was $\$ 671$ million. Repealing the franchise tax would reduce total revenue by $\$ 395$ million, or by $59 \%$. Moreover, the benefits to taxpayers would be heavily weighted to the largest corporations, with those with franchise taxable values over $\$ 1$ billion reducing their tax payments by approximately $\$ 4$ million and $85 \%$ of the net reduction accruing to corporations with a taxable base over $\$ 10$ million.

One reform possibility that has been discussed at the Louisiana Tax Institute is structuring the franchise tax as a minimum tax on corporate income. ${ }^{73}$ Corporations would pay the corporate income tax if their liability was greater than their franchise tax but would otherwise pay the franchise tax so that the franchise tax would serve as an alternative minimum tax. ${ }^{74}$ While that policy would also lose revenue, the revenue losses would only come from those corporations whose corporate income tax payments were lower than their

72 LA. DEP'T OF REVEnUE, Tabulations for Tax Year 2017 (2018) (on file with author).

73 See LA. TAX InST., Franchise Tax Scenario Handout, LA. DEP'T OF REVEnUE, https://revenue.louisiana.gov/LTI/LouisianaTaxInstituteMaterials [https://perma.cc/J6AE-QQ95].

${ }^{74} \mathrm{It}$ is an alternative minimum tax because it uses an alternative tax base for the corporate income tax calculation. 
franchise tax. New York and Connecticut currently structure their franchise taxes as minimum taxes.

If one believed that the single-entity corporate tax had the capacity for allowing significant profit-shifting, redeploying the franchise tax as a minimum tax could be a reasonable, though imperfect, backstop to the corporate tax. A recent study by the Louisiana Tax Institute discussed the potential benefits of combined reporting for curbing profit-shifting, but also raised the concern that moving away from single-entity taxation would make Louisiana an outlier in the South. ${ }^{75}$ Restructuring the franchise tax as a minimum tax would ensure that some corporate-level revenues would be derived from taxpayers with significant economic presence, in this case measured by the taxable base of the franchise tax. In a state where the populist tradition dating back to Huey Long still resonates, this is certainly a political plus.

The Louisiana Department of Revenue provided estimates of the effects of employing the franchise tax as a minimum tax. Table 2 below, in the same format as Table 1 , provides the revenue estimates and impact by taxable base for taxable year 2017. The data presented are after all allowable credits can be taken against both the corporate and franchise tax.

Table 2: Franchise Tax as a Minimum Tax

\begin{tabular}{|c|c|c|c|c|c|}
\hline $\begin{array}{l}\text { Taxable Base } \\
\text { Range }\end{array}$ & $\begin{array}{c}\text { Number } \\
\text { of } \\
\text { Returns }\end{array}$ & $\begin{array}{l}\text { Total After } \\
\text { Credits }\end{array}$ & $\begin{array}{c}\text { New Total } \\
\text { After } \\
\text { Credits }\end{array}$ & Difference & $\begin{array}{l}\text { Average } \\
\text { Difference }\end{array}$ \\
\hline Less than 0 & 17,759 & $11,317,022$ & $11,200,501$ & $-116,521$ & -7 \\
\hline $\mathbf{0}$ & 77,248 & $21,331,846$ & $21,330,190$ & $-1,656$ & 0 \\
\hline $1-25,000$ & 19,647 & $3,010,333$ & $2,951,253$ & $-59,080$ & -3 \\
\hline $25,001-100,000$ & 13,796 & $3,972,061$ & $3,710,171$ & $-261,890$ & -19 \\
\hline $100,001-500,000$ & 15,073 & $12,019,278$ & $10,646,403$ & $-1,372,875$ & -91 \\
\hline $500,001-1,000,000$ & 4,339 & $77,703,477$ & $75,945,020$ & $-1,758,457$ & -405 \\
\hline $\begin{array}{l}1,000,001- \\
10,000,000\end{array}$ & 6,645 & $74,945,614$ & $58,595,403$ & $-16,350,210$ & $-2,461$ \\
\hline $\begin{array}{l}10,000,001- \\
50,000,000\end{array}$ & 1,327 & $110,744,136$ & $86,221,259$ & $-24,522,877$ & $-18,480$ \\
\hline $\begin{array}{l}50,000,001- \\
100,000,000\end{array}$ & 243 & $59,382,074$ & $47,190,540$ & $-12,191,534$ & $-50,171$ \\
\hline $\begin{array}{l}100,000,001- \\
500,000,000\end{array}$ & 193 & $145,410,704$ & $111,616,857$ & $-33,793,847$ & $-175,098$ \\
\hline $\begin{array}{l}500,000,001- \\
1,000,000,000\end{array}$ & 32 & $68,653,352$ & $48,003,800$ & $-20,649,552$ & $-645,298$ \\
\hline$>1,000,000,000$ & 19 & $82,694,996$ & $60,526,883$ & $-22,168,113$ & $-1,166,743$ \\
\hline Total & 156,321 & $671,184,893$ & $537,938,280$ & $-133,246,613$ & -852 \\
\hline
\end{tabular}

75 See La. Tax Inst., Report to the Legislature on Corporate Income Tax Combined REPORTING 2019-001 (2019), http://revenue.louisiana.gov/Miscellaneous/TXI\%202019-001\%20MUCR \%20Report.pdf [perma.cc/7V6Y-83FN]. 
Source: Louisiana Department of Revenue, data for tax year $2017 .^{76}$

The revenue loss drops to $\$ 133$ million from $\$ 395$ million compared to straight repeal. This amount fits much more easily into the usual budget arithmetic facing the governor and legislature (at one point, Louisiana was spending nearly \$200 million per year in film credits). Under this proposal, the largest corporations do receive some benefits - the top 19 corporations by taxable base save about $\$ 1.2$ million in taxes.

The differences from Table 1 arise because some of these corporations paid very little in state corporation income taxes after credits. Results for tax year 2016 were quite similar, suggesting that at least for a few years, low state corporate income tax payments for firms with high franchise taxable value were systemic. Whether the low corporate income tax payments reflect avoidance activities, divergences between economic and taxable income, or simply convey information about real economic profitability is beyond the scope of this analysis.

This proposed policy has several positive design features. First, it continues to allow credits to be taken against corporate level taxes. One of the largest credits is for property taxes paid to local government on inventory; while the state legislature did not wish to have firms pay property taxes on inventories, they were not willing to prevent local governments from levying property taxes on inventories. As a result, they provided tax credits at the corporate or individual level for inventory taxes paid. Structuring the franchise tax as a minimum tax does not change that. Moreover, other credits (such as employment credits for the Quality Jobs program) can also be taken against the combined corporate payments. Second, the rules for the franchise tax are enshrined in Louisiana law. If there were changes that were desired, they could still be instituted through the normal legislative process. The base for the alternative minimum tax would not be outsourced to a third party.

Of course, there are other reforms that could be made to the franchise tax. It would not be difficult to remove many taxpayers from the tax entirely without much loss in revenue by only requiring corporations with taxable bases above a certain threshold to be subject to the tax. It would also be possible to reduce the rate, which is one of the highest in the country. The minimum tax proposal could be integrated with these changes. It does have the virtue of serving as a true backstop against a tax that potentially can be manipulated.

\section{CONCLUSION}

One way to summarize the arguments in this Article is to distinguish between a "mass tax" and a "boutique tax." A mass tax applies to a large number of taxpayers and is an intrinsic part of the overall tax base and tax system. A boutique tax is much more limited in scope and applies either to a small number of taxpayers or a smaller part of the tax base.

The United States has had extensive experience with the alternative minimum tax as a mass tax, both at the individual level and corporate level. At the individual level, it drifted from its original intention of ensuring some high-income taxpayers did not escape all tax to a system in which large numbers of the upper-middle class were subject to the tax and were an important source of overall tax revenue. It also increased tax complexity and most likely decreased knowledge about the operation of the actual tax system. For example, many of the complaints from taxpayers in high-tax states about the $\$ 10,000$ limit on state and local tax deductions were from those who had effectively already lost the

\footnotetext{
${ }^{76}$ LA. DeP'T OF REVENUE, supra note 72.
} 
deduction because of the alternative minimum tax. Large corporations who paid the bulk of the corporate alternative minimum tax were certainly aware of its provisions but had to plan around times when they would be subject to the tax and when they would not be in order to calculate the true cost of investment and their eligibility for tax credits.

For both systems, the links between the regular and minimum taxes were problematic. For the individual AMT, Congress only partially adjusted the AMT in response to changes in the regular tax and had an incentive not to make further adjustments in order to preserve revenue for more visible tax changes. At the corporate level, taxpayers were at times successful at forcing integration, but nonetheless there was always the risk that the credits provided in the regular tax system would not be available under the corporate AMT. As a mass tax, the AMTs operated at cross purposes from the regular tax law and had unpredictable and often inefficient consequences. It was not a positive experience, and the repeal of the corporate AMT and the temporary evisceration of the individual AMT do seem to be overall improvements in our tax structure.

To deal with the perception issue, I suggested that for individuals the tax provisions could be tackled directly - such as for incentive tax options-with limitations on NOLs (allowing for carryforwards) being a valuable component of the system. At low interest rates, the present value of deductions arising from NOL carryforwards will not be substantially less than the value to the taxpayer of immediate deductions. Therefore, the use of NOLs will not cause economic inefficiencies. For dealing with perceptions about corporate taxpayers, I suggested that corporations reframe their tax presentations, emphasizing global as well as state and local tax payments. The stigma of an amoral, nontaxpaying corporation could be eased if it were clearly demonstrated that taxes were being paid in a variety of jurisdictions.

This does leave room for boutique minimum taxes. In this Article, I suggested that a minimum tax on foreign earnings might be a reasonable compromise in the balance of taxing foreign versus domestic activity but that a full-fledged multilateral minimum tax was much less feasible and desirable. At the state level, I made a case for using the franchise tax only as an alternative minimum tax for state corporate income tax structures that were not robust to combat profit-shifting. Minimum taxes should be used like surgical tools in select situations, rather than as broad-based components of an overall tax system. 